\section{Part III Migration and Human Rights in the Former Soviet Union}

For 75 million non-Russians living in the territory of the former Soviet Union but outside the Russian Federation, and for 28 million non-Russians with their own national territories in the Russian Federation, constitutional and legal questions regarding citizenship, the state language, and conditions for ethnic minority life are a top priority. That is fully understandable: such laws massively affect their economic, political, social and cultural conditions.

If we analyze the laws passed by the new states of the region regarding citizenship we can draw conclusions about the degree of tolerance of the new states toward minority nationalities. Citizenship law is, after all, fundamental since it defines basic political and social rights.

People not native to the republics, especially residents who speak Russian, are very uncertain about their future in the new countries and they often try to obtain dual citizenship with Russia. However, at present dual citizenship is acknowledged only by the Armenian Constitution (article 10) and by the law "On Turkmenistan Citizenship" (article 9); as an exception, dual citizenship is allowed by the "Law on Citizenship of Moldova" (article 6), of Kazakhstan (article 3), of Russia (article 3), of Uzbekistan (article $10)$, and of Lithuania (article 1).

It is urgent that dual citizenship be negotiated between the countries of the region and agreements signed. But the new states have in general not tried to conclude such agreements. For its part, Russia has prepared and submitted to the Supreme Soviet the draft of a law that will allow one to obtain Russian citizenship without cancelling one's other citizenship. This can be viewed as an attempt to ease the problems of the Russian-speaking population in the former republics of the USSR.

Many heated disputes over whether to recognize dual citizenship took place when the constitutions of the new countries and autonomous republics (especially Tatarstan, YakutiaSakha and Bashkortostan) were being prepared. The law on citizenship of the Russian Federation specifies that citizens of Russia who live permanently in a republic within Russia are at the same time citizens of that republic. Republics within Russia are eligible to establish their own citizenship but are not entitled to limit the rights, freedoms and other interests obtained by virtue of Russian citizenship. However, the constitutions of Tatarstan and Yakutia-Sakha claim that these republics have the right to bestow or cancel citizenship of their republics. This contradicts the Russian constitution since Russia has reserved these rights for itself. This can have negative and discriminatory consequences for members of non-titular nationalities because, for example, they may consider themselves Russian while local law leaves them without legal protection from Russia.

Russian federal law attempts to guarantee protection of non-titular nationalities because it establishes the priority of the Russian Federation in citizenship regulations. Thus, according to federal statutes, it is illegal to establish conditions for citizenship apart from permanent residence in a republic.

Nonetheless, most of the laws on citizenship (and other regulations related to them) which have been approved by the former republics of the USSR contain, to varying degrees, conditions apart from residence for members of non-titular nationalities who wish to obtain citizenship. Only Lithuania, Ukraine and Russia accept the so-called "zero option" for citizenship. This means that all people residing in those states when their citizenship laws were passed and who have a legal source of subsistence need only to express the wish to become citizens. In all other new states, with the exception of Kazakhstan and Uzbekistan, knowledge of the national language has become mandatory for citizenship eligibility.

From the formal-legal point of view it is very difficult to discern in the constitutions and laws of the republics biases against non-titular nationalities. They pay tribute to democratic principles and declare the equality of citizens before the law and the absence of discrimination on the basis of nationality, sex, origin, faith, political views, social background and possession of property. They stress that foreign citizens who are residents of the republic and the citizens of the republic share equal rights and freedoms.

However, the way these regulations are implemented, together with additional norms and acts, reveal the actual policy that is being carried out in the republics, especially when applied to non-titular nationalities. In Estonia and Latvia, regulations regarding citizenship for members of non-titular nationalities are especially severe (see Table 8).

Hundreds of thousands of Russianspeaking inhabitants of the Baltic States are residents without citizenship, or even potential foreigners if they obtain Russian citizenship. The circumstances for the Russian-speaking population are thus critical. In some districts inhabited mainly by Russians, such as Narva and Estonia, the situation is grim and violence is possible.

As a consequence of the fact that citizenship is not available to everyone, people are exposed to discrimination in the political, social, cultural and welfare spheres. In Estonia, for example, non-citizens do not have the right to vote or be elected. In the recently elected parliament of Estonia there is not a single candidate to represent the roughly 25 percent of the population that is Russian-speaking. Non-citizens of Latvia do not have the right to form parties and social movements. Selfadministration of non-Latvian ethnic communities has been disallowed in places where non-Latvians compose a majority of the inhabitants. 
Baltic politicians can hardly justify limiting the rights of other nationalities by claiming that they are disloyal. They must remember that in March 1990 one-third of the Russian democratic movement voted for Estonian independence. Despite this support, however, Russian speakers enjoy limited rights. ${ }^{11}$

On the other hand, one cannot claim that the position of the Russian population in the former republics always meets the criteria of citizenship. Some Russians in the former Soviet republics still feel that they belong to a great power and that they are part of the Russian community and of Russian culture. Thus, 44 percent of the Russian population inhabiting both banks

of the Dniester river in Moldova believe that it is not necessary to know the language of the native ethnic group. ${ }^{12}$

Limitations on political rights may also be found in the constitutions of the other former republics of the USSR. For example, the constitutions of Moldova and Turkmenistan allow the opportunity to become President only to a member of a native ethnic group. Kazakhstan, Estonia and Latvia allow foreign business people-including those with Russian citizenship-to participate in privatization. But in Latvia 80 percent of privatization vouchers will go to the citizens of the republic and only 20 percent to noncitizens (including the half million

Table 8: Rights of the Russian-Speaking Population in the Baltic States

LITHUANIA

Zero option accepted by law; citizenship granted to everybody who lived in Latvia before June 1940, to their descendants, and to all residents who applied for citizenship before November 1989 (it is planned to extend this deadline to 1991).

Russian-speaking people have full rights to own property and participate in privatization.

\section{LATVIA \\ Citzenship: \\ EsTONIA}

Law on citizenship not yet passed; citizenship rights belong to residents who lived in Latvia before 1940 and their descendants; new law will be passed by the parliament elected in June 1993 without the participation of most of the Russian-speaking population (constituting 700,000 people, or about 30 percent of the total population).

\section{Property:}

Non-citizens lack right to participate in privatization but the Ministry of Economic Reforms can make exceptions regarding purchase of property.

\section{Voting:}

Only citizens have right to vote; further determination of voting rights will take place in the current parliament.
In November 1991, the 1938 law on citizenship restored, citzenship granted exclusively to pre-1940 residents of Estonia and their descendants (thus excluding about 450,000 residents-about a third of the country's population).

Russian-speaking people lack rights to buy land and to participate in privatization.
Russian-speaking people have right to vote in municipal elections only. non-citizens resident in Latvia). Perhaps this approach has been taken because such a large proportion of business people in Latvia are Russians and Jews.

As far as social rights are concerned, there are some limits for non-citizens in employment, education and career advancement. In Estonia and Latvia a series of positions in state institutions are designated for citizens only. In order to take advantage of many of the sociocultural rights that are constitutionally guaranteed one must know the state language and pass certain tests. The constitutions of Turkmenistan and Kazakhstan are the most tolerant toward minority languages. Moldova and Ukraine guarantee the use of the Russian language for interethnic communication and the parallel creation of conditions for learning the state language. It is not clear whether the Kirgiz Parliament will approve of Russian as a language for interethnic communication. At the moment the Russian language is used for administrative purposes in areas where Russian communities live.

In the republics of the Russian Federation the concept of two official languages is being discussed. In Bashkortostan there are three official languages due to its ethnic composition. In some Russian republics, where the majority of people belong to titular ethnic groups, various decisions have been made in favour of the language of the ethnic majority. Behind this are the leaders of the ethnic intelligentsia.

In Estonia, Latvia, Moldova and Ukraine regulations specify that certain jobs require knowledge of the state language. The Soviet of Ministers of Latvia passed an additional regulation (No. 189) that requires one to pass tests in the state language to qualify for work in state institutions. Employees are required to learn the state language in a very short period of time- - only six months. A concession is made for owners of private enterprises, who are not required to know Latvian. ${ }^{13}$

Kazakhstan is composed of about 40 percent Russians and 40 percent Kazakhs. Therefore, the language

Source: The Criminal Situation and Social Tension in the Russian Federation in 1992 
problem is not pressing and is facilitated by regulation No. 8 of the constitution banishing discrimination on the grounds of language. However, some members in the parliament think that it is necessary to amend the Criminal and Administrative Laws because ignorance of the language is being used by ethnic Kazakh bureaucrats to create ethnically homogeneous administrative bodies. Thus from 1985 to 1992, when sovereignty was being established in Kazakhstan, the number of higher Kazakh state officials increased to 420 while the number of non-Kazakhs in similar positions remained constant at the 1988 level of 300 . This is significant because it is this group of state officials that is so important in shoring up national stability. ${ }^{14}$ The situation is very similar in Tatarstan, where 70-75 percent of all administrative positions are held by Tatars; one can easily discern the creation of an ethnically-based state nomenklatura ${ }^{15}$ at the expense of the representatives of other minorities in all republics.

Discrimination on the grounds of language severely limits the rights of Russian speakers in employment and it renders people of pension age especially vulnerable. Nor is it easy to overcome language disabilities. There are few adult evening courses available in the state language and where such courses are available there is often only a very short period of time allowed to learn it. This violates international legal documents such as the General Declaration of Human Rights and the International Agreement on Political, Cultural and Social Rights.

In each of the former republics of the USSR the opportunity to receive higher and secondary education in non-state languages is substantially limited. For example, consider Article 10 of the Latvian Law on languages. It notes that the right to receive an education in one's native language is guaranteed for residents of Latvia. At the same time, it says that the state finances only those educational institutions where from the second year of study the state language, namely Latvian, is used.
In many other republics conditions which could facilitate the transition to the state language for the purposes of higher education are not yet in place. Methods and manuals for such instruction have not been worked out, especially for scientific-technical subjects. Very often teachers who belong to the native ethnic group do not know the state language well enough to teach it at a professional level even though in some republics a gradual transition to the state language is being planned. In Belarus, for example, the transition is planned for completion by the year 2000 . But the majority of the population favours the idea of two languages for educational purposes.

It is evident that the complete rejection of the Russian language from the sphere of education when scientific, technical and foreign literature is not available in the state languages will inevitably lead to the destruction of information flows and the degradation of science. The situation is reminiscent of that in North Africa. In Algeria, for example, the problem has not been solved up to the present. They rejected the French language in the 1970s and 1980 s, and immediately the problem of education became very complicated. Today the Algerians are taking a more pragmatic approach. In general, the experience of the developing countries is instructive: progress is quicker in those countries which are ready to compromise and use the language which had dominated earlier, parallel to the native state language.

Today the language problem is vital because it involves a large part of the non-native population in each republic. Only in Lithuania, Ukraine and Latvia is the percentage of Russianspeaking people with good ability in the native language high-33 percent, 25 percent and 20 percent, respectively. In Estonia and Moldova the corresponding figures are 10 percent and 12 percent, and in Kazakhstan and the other former republics of Central Asia 1-6 percent.

Thus in the "near abroad" the old approach to cultural and social problems has been revived and filled with political content. In this sphere officials miss the point that the development of language use must be of an evolutionary character and involve an interaction of cultures.

Migration in Russia and the former republics of the USSR has encouraged the passage of many laws governing migration. However, these bills, decrees and regulations leave unsolved the problem of the responsibility of the governments of the states of the former USSR. Specifically, it is unclear when they must protect the rights of residents who do not speak the titular nationality's language, compensate the material and financial losses of refugees, and pay the housing expenses of refugees.

The situation is dangerously aggravated by local bureaucrats and regulations. The uncontrolled mass migration of refugees intensifies political, social, economic, demographic and criminal problems. It prompts local authorities in Stavropol and Krasnodar, for example, to resort to their own measures in limiting the admission of refugees and migrants.

The CIS Inter-Parliamentary Assembly is supposed to coordinate national laws and overcome sharp differences in citizenship questions between the former republics of the USSR. However, its functions today are mostly decorative because its regulations are not binding. They are basically recommendations.

Nor are human rights regulated by international law. Many countries in the region consider such matters a purely domestic concern. More practical from the point of view of the protection of human rights are bilateral and multilateral treaties. They can protect people against discrimination in employment, education and housing. They can provide social protection, allocate responsibilities for settling refugees, take care of the transportation of the property of the migrants and compensate their expenses.

At present, attempts to settle the migration problem at the state level are not succeeding in Russia. There are very few initiatives to conclude inter-

(C) I. Orlova, Y. Streltsova, E. Skvortsova, 1994. This open-access work is licensed under a Creative Commons Attribution-NonCommercial 4.0 International License, which permits use, reproduction and distribution in any medium for non-commercial purposes, provided the original author(s) are credited and the original publication in Refuge: Canada's Journal on Refugees is cited. 